\title{
Entre o Direito e a Música
}

\section{Gabriela Caldeira \\ Musicista}

Resumo: Nesta comunicação ao V Colóquio Jushumanista Internacional, no Porto, Portugal, a autora reflete sobre as epistemai jurídica e musicial e a experiência do Direito e da Música.

Palavras Chave: Direito, Música, Interpretação, Interdisciplinaridade.

Abstract: In this paper, presented at the V "Colóquio Jushumanista Internacional", at Oporto, Portugal, the author reflects on the legal and musical epistemai and about the experience of Law and the experience of Music.

Keywords: Law, Music, Interpretation, Interdisciplinary.

Este não é um texto sobre Direito. Tão pouco eu possuo alguma habilitação ou formação jurídica que se poderia chamar de sólida; o mais longe que me aventurei nas calhas do Direito foi numa viagem pela Faculdade de Direito da Universidade do Porto para, ao cabo de dois anos, trocar as interpretações do texto jurídico pela do texto musical.

Parecia um confronto desigual; dir-se-ia talvez que parte para outras paragens mais distantes, onde não se fala nem lê em português e onde os seus habitantes têm o estranho hábito de comunicar através de meios que lhes são exteriores (assim se vê que é possível sermos estrangeiros na nossa própria Pátria, seja ela, como dizia o Poeta, a Língua Portuguesa ou ainda a pátria jurídica, a matemática, a científica, etc...).

Contudo no final, quebradas as barreiras políticas, cedo se vê que os habitantes dos dois lados da vedação possuem estranhamente a mesma compleição física, os mesmos olhos, o mesmo rosto, o mesmo sangue que corre nas veias e os mesmos desejos que os unem enquanto pessoas mas que os desunem enquanto nação.

E, por isso, este não é um texto sobre Direito nem é ainda um artigo sobre Música, mas sim um artigo sobre Artes. Porque o Direito é, ele mesmo, também uma arte.

Esperar-se-ia que a Música e o Direito pertencessem a dimensões muito diferentes, quase que intocáveis até, uma dependente da interpretação das mentes e a outra dos corações... contudo tal não poderia ser mais errado (nenhuma interpretação mental se pode desprover da emocional e vice-versa) e é precisamente aí que se esbate a primeira barreira entre as duas áreas.

Essa ponte é a Interpretação. Tanto o Direito como a Música possuem um suporte físico de natureza primariamente textual e, como tal, sujeito à percepção de um intérprete. 
Essa "mutabilidade na rigidez" do texto é uma das características mais interessantes destas duas artes e talvez com isso nos demos conta que o mérito não está na peça e sim no artista (também assim o Sol se move no firmamento, mas apenas aos nossos olhos!...).

E tanto a obra como o oleiro se transformam mutuamente, numa relação eterna de dependência, ele criando, ela recriando-o, porque o Homem recria-se pela Arte e pelo Intelecto.

Esta relação de dependência conduz-nos à segunda ponte aglutinadora: as duas artes exigem devotos dispostos para as seguir por toda a vida. Seja por necessidades de natureza diferente (a da Música de índole muscular e a do Direito do passo dos tempos...), a verdade é que, parando o coração do intérprete, acaba-se também o artista.

Tanto o Direito como a Música exigem uma dedicação constante, um estudo vitalício, marcado pelo ritmo e pelo amor à missão a que se propõe. Porque, se em quase todas as ocupações é necessário a dose certa de gosto e apreço, o Direito e a Música pertencem ao grupo daquelas que nunca darão fruto quando praticadas apenas por um artista que se ama a si próprio ou pelo montante fixo e efémero ao fim do mês.

E isto é muito importante uma vez que, se é à custa dos recursos monetários que se abrem as portas aos maiores progressos, é já à custa dos recursos intelectuais que se fazem as maiores mudanças.

Aponte-se também o infeliz facto de as artes do Direito e da Música serem vistas geralmente pelo público como parte integrante de uma classe intelectual "elitista".

Admira-se o juiz, o advogado, o pianista, o jurista, o cantor, etc., como manifestações de um nível que o cidadão comum nunca poderá atingir. Mas, se é verdade que nem todos somos escritores embora saibamos escrever, também é verdade que tanto a ordem jurídica como a musical são inerentes à condição humana: o Homem, na qualidade de animal social, político e sensível, encontra no Direito e na Música um talento natural, comparável aos das aves que constroem os ninhos ou ao das aranhas que constroem exímias teias sem quaisquer conhecimentos de engenharia. Cabe ao conhecimento o papel de melhoramento dos talentos que são naturais.

O discurso jurídico e musical são, portanto, de criação naturalmente humana e não é por acaso que ambas são artes milenares. Poderemos não ser todos juristas e músicos de profissão, mas é importante que o público entenda que pode ser um pouco jurista e músico de coração e que, por isso, isso é importante para o seu desenvolvimento enquanto pessoa e cidadão atrever-se a um estudo mais ou menos individual da cultura jurídica e musical do país.

Uma quarta ponte se insinua (esta será talvez a que poderá originar mais discórdia) e prende-se no facto de tanto o Direito como a Música serem artes que lidam com realidades de natureza abstracta, se é que me faço entender com este oximoro...

Tanto os conceitos musicais como os de ordenação são abstracções que o Homem, enquanto sonhador e criador, transportou para um suporte físico aplicável nas situações reais e práticas.

É também a essa abstracção que se deve a sua recriação constante pois o intérprete, diante de ambos os textos, reescreve-os constantemente. Contudo, uma ressalva: é certo que as consequências de uma má interpretação dos dois textos não são as mesmas e muitas vezes a má leitura de um texto jurídico pode conduzir a tragédias de ordem social e humana... 
Ainda assim, tal não é da responsabilização da natureza das fontes (que continua a ser abstracta) mas sim dos fins para que se propõem e esses são de escolha primordialmente humana; não será porque - e atrevo-me a esta metáfora simplista uma faca poder ser usada como arma que deixará de pertencer à mesma natureza de uma colher e também essa "diferença" entre o Direito e a Música é regida pelo uso das artes e não pelas artes em si mesmas.

Finalmente aquela que considero ser a ponte mais importante entre o Direito e a Música reside no facto de, acima de tudo, ambas constituírem deveres cívicos. A ordem jurídica não se presta apenas a garantir-nos direitos nem a música se presta apenas ai entretenimento.

Os direitos de um indivíduo constituem os deveres de outro e o entretenimento implicar necessariamente um "entertainer", que pode ser presente ou não. Num mundo em que, nas zonas mais beneficiadas pela boa arte do Direito, cada vez mais se clama por direitos e menos por deveres (o que, por serem correlativos, não fará grande sentido) e em que se desvirtua o sentido do Belo como sinónimo de futilidade e superficialidade, ao Direito e à Música - ou, mais precisamente, aos seus intérpretes cabe o papel transformador da sociedade.

Foi Mêncio, pensador confucionista do século III a.C., a ideia de que, da mesma forma que nunca uma terra por lavrar se conseguirá fazer medrar bom fruto, também numa mente humana macerada pelas agruras da existência não conseguirá crescer forte e viçosa. É imperioso cultivar-se o espírito humano e, com ele, o coração dos homens, com as sementes do Intelecto, da Ordem e da Beleza.

Na minha infância perguntei às mulheres da minha família, género que desde sempre foi mais sensível a essas subtilezas, o porquê da insistência em manter o meu quarto impecavelmente em estilo "museu" e tudo impecavelmente alinhado, coisas com coisas e cores com cores se eu à partida seria a única pessoa que iria "sofrer" com as consequências da falta de ordem e gosto... Responderam-me então que, quando nos encontramos rodeados de coisas belas e boas, tornamo-nos nós mesmos mais belos e bons.

Terminando com aquele que é o mais conhecido trecho escrito por São Paulo numa carta aos Coríntios,

"Ainda que eu falasse as línguas dos homens e dos anjos, e não tivesse amor, seria como o metal que soa ou como o címbalo que retine. E ainda que tivesse o dom de profecia, e conhecesse todos os mistérios e toda a ciência, e ainda que tivesse toda fé, de maneira tal que transportasse os montes, e não tivesse amor, nada seria.

E ainda que distribuísse todos os meus bens para sustento dos pobres, e ainda que entregasse o meu corpo para ser queimado, e não tivesse amor, nada disso me aproveitaria.

$O$ amor é sofredor, é benigno; o amor não é invejoso; o amor não se vangloria, não se ensoberbece, não se porta inconvenientemente, não busca os seus próprios interesses, não se irrita, não suspeita mal; não se regozija com a injustiça, mas se regozija com a verdade; tudo sofre, tudo crê, tudo espera, tudo suporta.

O amor jamais acaba; mas havendo profecias, serão aniquiladas; havendo línguas, cessarão; havendo ciência, desaparecerá; porque, em parte conhecemos, e em parte profetizamos; mas, quando vier o que é perfeito, então o que é em parte será aniquilado.

Quando eu era menino, pensava como menino; mas, logo que cheguei a ser homem, acabei com as coisas de menino. Porque agora vemos como por espelho, em 
enigma, mas então veremos face a face; agora conheço em parte, mas então conhecerei plenamente, como também sou plenamente conhecido.

Agora, pois, permanecem a fé, a esperança, o amor, estes três; mas o maior destes é o amor."

E, à semelhança do Amor (substitua-se o termo pela Beleza), é só através da sensibilidade ao Belo e à Ordem (que é a Beleza de ordem social) conseguirá o Homem libertar-se da rudeza e dos grilhões impostos por uma vida encarcerada exclusivamente no culto da Razão bruta...

Recebido para publicação em 05-09-15; aceito em 02-10-15 